\title{
Pengaruh Deksametason 0,2 mg/KgBB Sebagai Adjuvan Analgesia terhadap Waktu Kejadian Nyeri Pascaoperasi Odontektomi dengan Nrs $>3$
}

\author{
Jose Domingos, ${ }^{1}$ Suwarman, ${ }^{2}$ Nurita Dian Kestriani ${ }^{2}$ \\ ${ }^{1}$ Guido Valaderes Hospital Nasional, Timor Leste, ${ }^{2}$ Departemen Anestesiologi dan Terapi Intensif \\ Fakultas Kedokteran Universitas Padjadjaran/RSUP Dr. Hasan Sadikin Bandung
}

\begin{abstract}
Abstrak
Deksametason merupakan kortikosteroid golongan glukokortikoid yang memiliki efek anti inflamasi yang adekuat. Penelitian ini bertujuan menilai waktu nyeri pertama kali dengan NRS $>3$ pada pasien pascaoperasi odontektomi. Penelitian ini merupakan uji acak terkontrol buta ganda pada 30 pasien dengan status fisik American Society of Anesthesiologist kelas 1 (ASA I) yang menjalani operasi odontektomi dalam anestesi umum di Rumah Sakit Dr. Hasan Sadikin Bandung periode Agustus-September 2019. Pasien dibagi menjadi dua kelompok, yaitu 15 pasien yang menerima deksametason (D) dan 15 pasien plasebo (K). Penilaian skala nyeri menggunakan nilai numeric rating scale pada NRS $>3$ pertama kali. Analisis statistika data hasil penelitian menggunakan chi square dan Mann-Whitney. Hasil penelitian menunjukkan waktu pertama kali terjadi nyeri dengan NRS $>3$ lebih lama pada kelompok D dibanding dengan kelompok plasebo dengan perbedaan bermakna $(p<0,05)$. Simpulan penelitian ini adalah pemberian deksametason $0,2 \mathrm{mg} / \mathrm{kgBB}$ sebagai adjuvan analgesia terhadap waktu kejadian nyeri dengan NRS $>3$ pada pasien pascaoperasi odontektomi menghasilkan waktu yang lebih lama.
\end{abstract}

Kata kunci: Adjuvan analgesia, deksametason, numeric rating scale, nyeri pascaoperasi

\section{Effect of Dexamethasone $0.2 \mathrm{mg} / \mathrm{KgBW}$ as Analgesia Adjuvant on Post- Operative Odontectomy Pain with Nrs $>3$ Occurence}

\begin{abstract}
Dexamethasone is a glucocorticoid corticosteroid that has the strongest anti-inflammatory effect. The aim of this study was to assess the time of the first pain with NRS $>3$ in post-operative odontectomy patients. This study was an experimental randomized double blind controlled trial involving 30 patients with physical status ASA I whounderwent odontectomy under general anesthesia in Dr. Hasan Sadikin General Hospital Bandung during August-September 2019. Patients were divided into two groups: 15 patients received dexamethasone and 15 patients received placebo. Pain scale assessment was performed using the numeric rating scale (NRS) in post-operative patients with first pain with NRS $>3$. Data collected were analyzed statistically using chi square and Mann-Whitney and the results showed a significantly longer first pain with NRS $>3$ in the placebo group $(\mathrm{p}<0.05)$. Hence, $0.2 \mathrm{mg} / \mathrm{kg}$ body weight dexamethasone as an adjuvant analgesia produces better analgesia against the occurrence of pain with NRS $>3$ in post-operative odontectomy patients that enable analgesic dose reduction.
\end{abstract}

Key words: Adjuvant analgesia, dexamethasone, numeric rating scale, postoperative pain

Korespondensi: Jose Domingos, dr., SpAn, Guido Valadares National Hospital, Jl. Bidau Dili Timor Leste, Tlpn +670 7307 1205, Email: aze1524@yahoo.com 


\section{Pendahuluan}

Nyeri pascaoperasi merupakan nyeri yang dihasilkan dari suatu proses inflamasi yang disebabkan oleh insisi dan kerusakan jaringan sehingga terjadi pelepasan mediator inflamasi yang mengaktifasi nosiseptor maka terjadi sensitisasi perifer. Penanganan nyeri pascaoperasi yang tidak baik akan meningkatkan komplikasi klinis dan psikologis sehingga dapat meningkatkan morbiditas, mortalitas, biaya perawatan, dan menurunkan kualitas hidup. ${ }^{1,2}$

Impaksi molar ketiga merupakan penyakit dengan prevalensi tinggi seperti di India mencapai 44,7\% dan lebih dari setengahnya memerlukan operasi dengan anestesi umum. Tindakan operasi odontektomi menyebabkan nyeri, trismus, dan pembengkakan akibat operasi serta reaksi peradangan yang menimbulkan ketidaknyamanan pascaoperasi. Reaksi radang ini lebih besar jika jumlah gigi yang dicabut semakin banyak dengan derajat nyeri sedang sampai berat. ${ }^{2-4}$

Penggunaan adjuvan analgesia dapat meningkatkan derajat analgesia ketika diberikan bersamaan dengan analgesia yang lain sehingga mengurangi kebutuhan opiod pascaoperasi dan mempercepat masa pemulihan. Salah satu adjuvan yang sering diberikan adalah deksametason. Deksametason merupakan kortikosteroid dengan efek anti-inflamasi yang adekuat yang memiliki pengaruh menghambat proses nyeri. ${ }^{2-12}$

Penggunaan deksametason sebagai adjuvan analgesia pascaoperasi odontektomi di luar negeri telah menjadi salah satu pilihan. Dosis deksametason sebagai adjuvan pascaoperasi dipergunakan dalam penelitian berkisar $0,11-0,21 \mathrm{mg} / \mathrm{kgBB}^{2-12}$

Tujuan penelitian ini adalah mengetahui efek pemberian deksametason sebagai adjuvan analgesia pada waktu kejadian nyeri pertama kali dengan NRS $>3$ pada pasien pascaoperasi odontektomi.

\section{Subjek dan Metode}

Penelitian menggunakan desain uji acak buta ganda (double blind randomized trial). Subjek penelitian adalah seluruh pasien yang menjalani operasi odontektomi elektif periode Agustus sampai September 2019 dalam anestesi umum dan memenuhi kriteria inklusi dan tidak termasuk ekslusi. Kriteria inklusi adalah usia 19 tahun sampai 50 tahun, menjalani operasi odontektomi 2 gigi, dan status fisik American Society of Anesthesiologists (ASA) kelas I. Kriteria eksklusi adalah riwayat alergi terhadap obat anestesi, mempunyai riwayat penyakit ulkus peptikum, sedang mendapat terapi analgetik (opioid, tramadol, parasetamol, obat antiinflamasi nonsteroid), dan skala Hamilton anxiety rating scale $>25$ (kecemasan berat).

Penentuan besar sampel dilakukan berdasar perhitungan statistik untuk perbandingan dua rerata tidak berpasangan dengan menetapkan taraf kepercayaan 95\% dan kuasa uji (power test) 80\%. Berdasar perhitungan didapatkan jumlah sampel minimal untuk tiap-tiap kelompok 15 orang sehingga total sampel 2 kelompok adalah 30 orang. Pengambilan sampel dilakukan secara consecutive sampling dan alokasi subjek ke dalam kelompok dilakukan secara blok permutasi.

Penelitian dilakukan di RSUP Dr. Hasan Sadikin Bandung pada bulan Agustus hingga Sepetember 2019 setelah mendapatkan persetujuan dari Komite Etik Penelitian Kesehatan Rumah Sakit Dr. Hasan Sadikin Bandung Fakultas Kedokteran Universitas Padjadjaran No: LB.02.01/X.6.5/248/2019. Peserta penelitian yang memenuhi kriteria inklusi dan tidak termasuk kriteria eksklusi diberikan penjelasan mengenai prosedur penelitian serta penandatanganan persetujuan (informed consent) pada saat preoperasi.

Peralatan yang digunakan dalam penelitian ini meliputi alat pengukur berat badan, kateter vena No 20G, set infus, three way merek Stop, syringe 3,5,10 mL, stop watch, laringoskop, pipa endotrakeal, monitor tekanan darah, laju nadi, saturasi oksigen perifer, elektrokardiografi (EKG), mesin anestesi, alat tulis, dan formulir penelitian.

Pada 15 menit sebelum induksi anestesi umum, kelompok D diberikan deksametason 
Tabel 1 Perbandingan Umum Karakteristik Subjek Penelitian Kedua Kelompok

\begin{tabular}{|c|c|c|c|}
\hline \multirow{3}{*}{ Variabel } & \multicolumn{2}{|c|}{ Kelompok } & \multirow{3}{*}{ Nilai p } \\
\hline & D & $\mathbf{K}$ & \\
\hline & $n=15$ & $n=15$ & \\
\hline Usia (tahun) & & & 0,233 \\
\hline Mean \pm Std & $26,80 \pm 8,152$ & $24,47 \pm 8,123$ & \\
\hline Median & 24,00 & 20,00 & \\
\hline Range (min.-maks.) & $18,00-47,00$ & $18,00-46,00$ & \\
\hline Status pendidikan & & & 0,256 \\
\hline Pelajar SMA & $11(73,3 \%)$ & $8(53,3 \%)$ & \\
\hline Mahasiswa/i & $4(26,7 \%)$ & $7(46,7 \%)$ & \\
\hline Berat badan (kg) & & & $\mathbf{0 , 7 9 4}$ \\
\hline Mean \pm Std & $53,93 \pm 9,874$ & $53,13 \pm 6,368$ & \\
\hline Median & 50,00 & 55,00 & \\
\hline Range (min.-maks.) & $40,00-70,00$ & $45,00-63,00$ & \\
\hline BMI $\left(\mathrm{kg} / \mathrm{m}^{2}\right)$ & & & 0,606 \\
\hline Mean \pm Std & $21,64 \pm 2,883$ & $21,13 \pm 2,386$ & \\
\hline Median & 20,88 & 21,42 & \\
\hline Range (min.-maks.) & $17,77-25,74$ & $17,02-24,60$ & \\
\hline Lama operasi (menit) & & & 0,959 \\
\hline Mean \pm Std & $104,66 \pm 18,942$ & $104,33 \pm 16,460$ & \\
\hline Median & 100,00 & 100,00 & \\
\hline Range (min.-maks.) & $80,00-135,00$ & $80,00-130,00$ & \\
\hline Tingkat ansietas & & & 1,000 \\
\hline Ringan (skala 7-14) & 11 & 11 & \\
\hline Sedang (skala 15-27) & 4 & 4 & \\
\hline
\end{tabular}

Keterangan: untuk data numerik nilai p diuji dengan uji T tidak berpasangan apabila data berdsitribusi normal dengan alternatif Uji Mann Whitney apabila data tidak berdistribusi normal. Nilai kemaknaan berdasar nilai $\mathrm{p}<0,05$.Tanda* menunjukkan nilai $\mathrm{p}<0,05$ artinya signifkan atau bermakna secara statistik

$0,2 \mathrm{mg} / \mathrm{kgBB}$ yang diencerkan menjadi $5 \mathrm{~mL}$ menggunakan $\mathrm{NaCl}$ 0,9\% dan diberikan secara intravena (i.v.), dan kelompok $\mathrm{K}$ (kontrol) diberikan plasebo yang berupa $\mathrm{NaCl} 0,9 \%$ sebanyak $5 \mathrm{~mL}$. Anestesi yang dilakukan adalah anestesi umum menggunakan fentanil $2 \mu \mathrm{g} / \mathrm{kgBB}$ i.v., propofol $2 \mathrm{mg} / \mathrm{kgBB}$ i.v., dan atrakurium 0,5 mg/kgBB i.v., untuk mencapai kedalaman anestesi yang adekuat sebelum dilakukan intubasi endotrakeal. Rumatan anestesi menggunakan Isofluran 1,2-2 vol\%, $\mathrm{N}_{2} \mathrm{O}: \mathrm{O}_{2}=50 \%: 50 \%$. Sebelum jahitan operasi yang terakhir selesai pasien diberikan analgetik parasetamol $1 \mathrm{~g}$ i.v., Lama operasi diukur dengan stopwatch oleh peneliti satuan waktu menit, hasil lama operasi dicatat dengan pembulatan waktu setiap 5 menit. Observasi penelitian dilakukan selama subjek di ruang pemulihan selama 4 jam. Tim peneliti mencatat lama waktu pasien menggunakan stopwatch dalam satuan waktu jam sejak tindakan operasi selesai $\left(\mathrm{T}_{0}\right)$ sampai pasien mengeluhkan nyeri pertama kali dengan NRS $>3$.

Analisis statistik untuk data ordinal menggunakan uji Mann Whitney dan untuk data kategorik dengan uji chi-square. Data hasil penelitian dicatat dan diolah menggunakan 
Tabel 2 Penilaian Waktu Kejadian Nyeri Pascaoperasi dengan NRS >3

\begin{tabular}{|c|c|c|c|}
\hline \multirow{3}{*}{$\begin{array}{c}\text { Waktu Pertama Kali Pasien Merasa Nyeri } \\
\text { (jam) }\end{array}$} & \multicolumn{2}{|c|}{ Kelompok } & \multirow{3}{*}{ Nilai p } \\
\hline & D & $\bar{K}$ & \\
\hline & $n=15$ & $n=15$ & \\
\hline Mean \pm Std & $3,80 \pm 0,414$ & $1,46 \pm 0.516$ & $0,0001^{* *}$ \\
\hline Median & 4,00 & 1,00 & \\
\hline Range (min.-maks.) & $3,00-4,00$ & $1,00-2,00$ & \\
\hline
\end{tabular}

Keterangan: untuk data numerik nilai p diuji dengan uji T tidak berpasangan apabila data berdsitribusi normal dengan alternatif Uji Mann Whitney apabila data tidak berdistribusi normal..Nilai kemaknaan berdasar nilai $\mathrm{p}<0,05$. Tanda* menunjukkan nilai $\mathrm{p}<0,05$ artinya signifkan atau bermakna secara statistik

program statistical product and service solution (SPSS) versi 24.0 for windows.

\section{Hasil}

Penelitian dilakukan terhadap 30 pasien dengan status fisik ASA I yang menjalani operasi odontektomi elektif dengan anestesi umum di COT lantai 3 dan 4 di RSUP Dr. Hasan Sadikin Bandung yang memenuhi kriteria inklusi dan tidak termasuk kriteria eksklusi.

Hasil analisis statistika menunjukan bahwa karakteristik umum subjek penelitian berdasar usia, status pendidikan, berat badan, body mass index (BMI), lama operasi (menit), dan tingkatansietas pada kelompok pemberian deksametason (D) dan kelompok kontrol (K) didapatkan hasil yang tidak berbeda signifikan ( $p>0,05$; Tabel 1).

Waktu nyeri pertama kali NRS >3 pascaoperasi pada pada kelompok pemberian deksametason (D) lebih lama dibanding dengan kelompok kontrol $(\mathrm{K})$ dengan hasil yang berbeda signifikan $(p<0,05$; Tabel 2$)$.

\section{Pembahasan}

Penanganan nyeri pascaoperasi bertujuan memulihkan fungsi organ secara cepat dan menghindari komplikasi. Penanganan nyeri pascaoperasi yang baik akan memperbaiki kualitas pelayanan kesehatan, mencegah morbiditas dan komplikasi pascaoperasi, meningkatkan kenyamanan dan kepuasan pasien, mempercepat penyembuhan, serta mengurangi biaya perawatan rumah sakit. ${ }^{1,2,13}$
Gambaran karakteristik umum subjek penelitian kelompok D dan $\mathrm{K}$ berdasar usia, berat badan, BMI dan lama operasi tidak berbeda bermakna secara statistik $(p>0,05)$. Berdasar hasil tersebut disimpulkan bahwa kedua kelompok adalah homogen dan layak dibandingkan.

Salah satu faktor yang dapat menyebabkan tingkatkeparahan pada nyeriakutpascaoperasi adalah tekanan terhadap emosi seseorang, kecemasan serta depresi. Seorang dengan tingkat kecemasan yang tinggi diperkirakan lebih reaktif terhadap pemberian rangsangan atau stimuli. Pada penelitian ini presepsi subjek terhadap kecemasan mempergunakan Hamilton anxiety rating scale (HARS) dan didapatkan bahwa tingkat kecemasan prabedah antara kedua kelompok ini secara statistik tidak berbeda bermakna $(p>0,05)$. Derajat nyeri pascaoperasi dipengaruhi oleh beberapa faktor di antaranya adalah usia, berat badan, BMI, dan lama operasi., ${ }^{3,13}$

Respons nyeri pada usia muda lebih tinggi dibanding dengan usia tua karena pada usia muda lebih cepat mengekspresikan nyeri dibanding dengan orang tua yang lebih menerima respons terhadap nyeri dan kecenderungan untuk tidak melaporkan nyeri yang dirasakan. Keluhan nyeri juga semakin besar sesuai dengan peningkatan berat badan dan BMI. Hal ini berkaitan dengan jaringan lemak yang meningkat dapat menghasilkan metabolit aktif serta melepaskan sitokin dan mediator-mediator proinflamasi. Faktor lama operasi juga memengaruhi derajat nyeri pascaoperasi karena meningkatkan pelepasan 
mediator proinflamasi. ${ }^{3,13,14}$

Penelitian ini melakukan pengukuran derajat nyeri dengan menggunakan numerical rating scale (NRS) yang dilakukan pada saat pertama kali pasien merasakan nyeri dengan NRS $>3$. Waktu Pertama kali pasien merasa nyeri dengan NRS $>3$ pada kelompok D lebih lama dibanding dengan kelompok K. Pada kelompok D rerata waktu pertama kali pasien merasa nyeri adalah pada jam ke-3 dan jam ke-4, sedangkan rerata waktu pertama kali pasien merasa nyeri pada kelompok $\mathrm{K}$ adalah pada jam ke-1 dan jam ke- 2 .

Nyeri pascaoperasi yang disebabkan oleh proses inflamasi terjadi karena kerusakan jaringan akibat sayatan pembedahan. Sayatan pembedahan tersebut menyebabkan respons metabolik yang disertai peningkatan sitokin proinflamasi seperti IL-1ß, IL-6, dan TNF- $\alpha$. ${ }^{2,3,15-18}$

Sitokin proinflamasi berupa interleukin (IL) 1 beta, interleukin IL-6, tumor nercotizing factor (TNF) alfa, dan lipopolisakarida tersebut akan merangsang sistem saraf pusat menyebabkan hiperalgesia dengan cara meningkatkan regulasi enzim cyclooxygenase 2 (COX-2). Enzim COX 2 tersebut mengubah asam arakidonat menjadi prekursor prostanoid (PGH2), prostaglandin. Prostaglandin isoform dan tromboksan akan mengaktivasi respons imun, inflamasi, dan meningkatkan nyeri. Prostaglandin E2 (PGE2) adalah enzim eikosanoid predominan yang ditimbulkan akibat trauma pembedahan dan dikaitkan dengan terjadi proses inflamasi, dan nyeri. ${ }^{15-18,19}$

Penggunaan deksametason sebagai glukokortikoid pascaoperasi telah banyak diteliti untuk menurunkan derajat nyeri. Deksametason menekan proses inflamasi pada luka operasi dan juga menekan proses nyeri dengan cara menekan produksi asam arakidonat, TNF-alfa, dan interleukin-1. ${ }^{2,3,6-14}$

Sayatan operasi akan mengaktifkan banyak reseptor nosiseptik dan akan mengubah stimulus tersebut ke suatu aksi potensial (transduksi). Aksi potensial tersebut diteruskan ke pusat pengaturan nyeri di medula oblongata (transmisi). Aksi potensial ini akan diolah melalui sistem informasi yang meningkatkan atau menghambat sensasi nyeri tersebut (modulasi). Proses modulasi banyak dipengaruhi oleh afeksi dan pengalaman terdahulu mengenai nyeri. Informasi yang sudah diolah akan diteruskan ke korteks serebri sebagai informasi final yang diterima otak (persepsi).,3,15-18

Proses transduksi dipengaruhi oleh banyak faktor dalam perubahan aksi potensial nyeri. Nyeri yang ditimbulkan oleh sayatan operasi yang langsung diakibatkan oleh cedera jaringan akan langsung diubah menjadi aksi potensial. Nyeri lanjutan pascaoperasi disebabkan oleh salah satunya proses inflamasi yang terjadi di sekitar jaringan. Inflamasi akan menyebabkan perubahan permeabilitas pembuluh darah dan menyebabkan pelepasan mediator-mediator inflamasi. ${ }^{2,3,15-18}$

Deksametason merupakan kortikosteroid dengan efek anti-inflamasi paling kuat yang bekerja dengan cara menghambat pembentukan prostaglandin pada jaras enzim cyclooxigenase (COX). Penekanan produksi prostaglandin di jaringan perifer akan mengganggu mekanisme penghantaran impuls nyeri. Deksametason juga menghambat aktivasi interleukin, tumor necroting factor, nitrit oksida, dan sitokin yang berperan dalam proses inflamasi. Efek deksametason tersebut yang berperanan sebagai adjuvan analgesia pascaoperasi. $3,6,14,17,19$

Deksametason merupakan sintetik dari glukokortikoid yang mempunyai efek mineralkortikoid minimal dan masa kerja panjang dan mempunyai efek antiinflamasi yang kuat setara 25-30 kali potensi hidrokortison serta 17 kali potensi prednison. Deksametason memiliki waktu paruh kerja yang panjang dibanding dengan hidrokortison atau metilprednison sehingga dapat digunakan sebagai adjuvan analgesia pascaoperasi dosis tunggal. Deksametason juga mengurangi inflamasi dan mempunyai efek menurunkan PONV, NRS pada operasi odontektomi. ${ }^{3,16,17}$

Pada penelitian di Spanyol dan India tentang penggunaan deksametason sebagai adjuvan analgesia pada pascaoperasi odontektomi molar ketiga didapatkan hasil 
bahwa deksametason dapat meningkatkan profil analgesia, menurunkan pembengkakan, dan mencegah trismus pada 24 jam pertama. Penelitian di RSHS tentang penggunaan deksametason sebagai adjuvan analgesia pascaoperasi dinyatakan bahwa deksametason baik untuk mengurangi proses inflamasi dan nyeri pada pasien yang dilakukan radikal mastektomi termodifikasi. Penelitian di China yang membandingkan dosis efektif deksametason menemukan bahwa dosis $0,2 \mathrm{mg} / \mathrm{kgBB}$ merupakan dosis yang efektif menurunkan VAS secara signifikan pada pasien pascakuretase. ${ }^{12,20}$

\section{Simpulan}

Waktu yang di perlukan untuk terjadi nyeri pertama kali dengan NRS $>3$ pascaoperasi odontektomi pada pasien yang diberi deksametason 0,2 mg/kgBB sebagai adjuvan analgesia lebih lama dibanding dengan pasien yang tidak diberi deksametason.

\section{Daftar Pustaka}

1. Warfiled C, Kahn C, Sevarino FB. Acute pain management: programs in US Hospitals and experiences and attitudes among US adults. Surv Anesthesiol. 1996;40(6):384.

2. Herrera-Briones FJ, Sánchez EP, Botella CR, Capilla MV. Update on the use of corticosteroids in third molar surgery: systematic review of the literature. Oral Surg Oral Med Oral Pathol Oral Radiol. 2013;116(5):342-51.

3. Raakesh N, Ravi V, Ushass P, Painatt J, Kumar V, Sasikumar P, dkk. Role of corticosteroids in reducing postoperative swelling, pain, and trismus following surgical extraction of impacted mandibular third molars. Int J Oral Care Res. 2017 01/01;5:265-9.

4. Ata-Ali Mahmud, Javier F, Oltra D, Diago M. Corticosteroids use in controlling pain, swelling and trismus after lower third molar surgery use in controlling pain, swelling and trismus after lower third molar surgery. J Clin Exp Dent. 2011;3(5):469-75.
5. De Oliveira GS, Almeida MD, Benzon HT, McCarthy RJ. Perioperative single dose systemic dexamethasone for postoperative PainA meta-analysis of randomized controlled trials. Anesthesiology. 2011;115(3):575-88.

6. Loveridge R, Patel S. Systemic non-opioid adjuvant analgesics: their role in acute postoperative pain in adults. Anaesth Crit Care. 2014;4(1):10-8.

7. Carvalho B, Butwick AJ. Postcesarean delivery analgesia. Best Pract Res Clin Anaesthesiol. 2017;31(1):69-79.

8. Erlangga $\mathrm{ME}$, Sitanggang $\mathrm{RH}$, Bisri $\mathrm{T}$. Perbandingan pemberian deksametason $10 \mathrm{mg}$ dengan $15 \mathrm{mg}$ intravena sebagai adjuvan analgetik terhadap skala nyeri pascabedah pada pasien yang dilakukan radikal mastektomi termodifikasi. JAP. 2015;3(3):146-54.

9. Rujirojindakul $\mathrm{P}$, Atchariyasathian V, Uakritdathikran T, Boonyata N, Boonthida Saefung B. Effect of dexamethasone on postoperative pain after adult tonsillectomy. Thai J Anesthesiol. 2008;34:1-8.

10. Kardash KJ, Sarrazin F, Tessler MJ, Velly AM. Single-dose dexamethasone reduces dynamic pain after total hip arthroplasty. Anesth Analg. 2008;106(4):1253-7.

11. Bisgaard T, Klarskov B, Kehlet H, Rosenberg J. Preoperative dexamethasone improves surgical outcome after laparoscopic cholecystectomy: a randomized doubleblind placebo-controlled trial. Ann Surg. 2003;238(5):651.

12. Quan Z-F, Tian M, Chi P, Li X, He H-L. Effective analgesic dose of dexamethasone after painless abortion. Int J Clin Exp Med. 2014;7(8):2144.

13. Kidd B, Urban L. Mechanisms of inflammatory pain. $\mathrm{Br} \mathrm{J}$ Anaesth. 2001;87(1):3-11.

14. Macres SMF. Acute pain management. Dalam: Barash P, Barash PG, Cullen BF, Stoelting RK, Cahalan MK, Stock MC, dkk., penyunting. Clin Anesth. Edisi ke-7. Philadelphia: Lippincot William \& Wilkins; 2016. hlm. 3919-4008. 
15. Lui F, Ng K-FJ. Adjuvant analgesics in acute pain. Expert Opin Pharmacother. 2011;12(3):363-85.

16. Ramaswamy S, Wilson JA, Colvin L. Non opioid based adjuvant analgesia in perioperative care. Crit Care Med. 2013;13(5):152-7.

17. Salerno A, Hermann R. Efficacy and safety of steroid use for postoperative pain relief: update and review of the medical literature. J Bone Joint Surg Am. 2006;88(6):136172.

18. Coutinho AE, Chapman KE. The anti- inflammatory and immunosuppressive effects of glucocorticoids, recent developments and mechanistic insights. Mol Cell Biol. 2011;335(1):2-13.

19. Hamilton M. The assessment of anxiety states by rating. $\mathrm{Br} \mathrm{J}$ Health Psychol. 1959;32(1):50-5.

20. Baldini G, Miller T. Chronic pain management. Dalam: Butterworth JF, Mackey DC, Wasnick JD, penyunting. Morgan \& Mikhail's clinical anesthesiology. Edisi ke-6. New York, N.Y: McGraw-Hill Education; 2018. hlm. 1887-919. 